\title{
Connection between psychological holistic factor and life satisfaction in old age - propensity score methods
}

\author{
Związek czynnika psychologicznego w ujęciu holistycznym z zadowolenia z życia w podeszłym wieku \\ - metody propensity score
}

\section{Boris Miha Kaučičc ${ }^{\text {, }}$ Bojana Filej2${ }^{2}$, Marija Ovsenik ${ }^{3}$}

\author{
${ }^{1}$ College of Nursing in Celje \& Alma Mater Europaea - ECM, Slovenia \\ ${ }^{2}$ College of Nursing in Celje \& Faculty of Health Sciences Novo mesto, Slovenia \\ ${ }^{3}$ Faculty of Organisation Studies in Novo mesto \& Alma Mater Europaea - ECM, Slovenia
}

CORRESPONDING AUTHOR/AUTOR DO KORESPONDENCJ:

Boris Miha Kaučič

College of Nursing in Celje \& Alma Mater Europaea - ECM, Slovenia

tel. 38651394363

e-mail:miha.kaucic@vzsce.si

\section{STRESZCZENIE ZWIAZEK CZYNNIKA PSYCHOLOGICZNEGO W UJECIU HOLISTYCZNYMZZADOWOLENIA ZŻYCIA W PODESZLYM WIEKU}

\section{- MEIODY PROPENSIIY SCORE}

Wprowadzenie. Holizm nie był tematem zbyt wielu badań w zakresie zdrowia i gerontologii społecznej. Starszy człowiek jest całością, dlatego potrzebuje holistycznego leczenia.Oznacza to, że bierzemy pod uwage jego potrzeby bio-psycho-społeczne a także duchowe. Celem tego badania jest określenie związku czynnika psychologicznego w ujęciu holistycznym z zadowolenia z życia w podeszłym wieku.

Materiał i metody. Przeprowadzono badanie kwestionariuszowe oraz analizę ilościową wyników badań. Losowa próba badawcza została wybrana ze zbioru statystycznego. Ankieta obejmowała 1064 osoby w podeszłym wieku ze Słowenii (mających 65 lat lub więcej) $z$ dziesięciu regionów statystycznych; brani pod uwagę respondenci mieszkają w środowisku domowym ( $\mathrm{n}=532$ ) lub instytucjonalnym ( $\mathrm{n}=532)$. Realizacja próby badawczej wyniosła 61,6\% (656 poprawnych ankiet). Według danych demograficznych, udział w badaniu wzięło 470 (71,6\%) kobiet i 186 (28,4\%) mężczyzn. Średnia wieku wyniosła 78,2 lata. Wyniki były analizowane z użyciem programu R MICE. Do analizy związków przyczynowych oraz warunkowych użyto zaawansowanych metod statystycznych, takich jak metoda propensity score.

Wyniki. Uzyskane wyniki sugerują naukowy wkład w zarządzanie jakością życia osób starszych oraz w ich jakość życia. Na podstawie obliczeń statystycznych można potwierdzić hipotezę mówiącą, że czynnik psychologiczny w ujęciu holistycznym $\left(R^{2}=0,21\right)$ odnosi się do zadowolenia z życia. Udowodniliśmy, iż następujące wskaźniki: kontakty społeczne $\left(R^{2}=0,176\right)$, pozytywne emocje $\left(R^{2}=0,366\right)$, samotność $\left(R^{2}=0,151\right)$ i zdolności poznawcze $\left(R^{2}=0,162\right)$ analizowane w obrębie psychologicznego czynnika w ujęciu holistycznym mają wpływ na zadowolenie z życia.

Dyskusja i wnioski. Badanie potwierdziło, że jeśli chodzi o czynnik społeczny, wskaźnikiem najbardziej związanym z zadowoleniem zżycia jest wskaźnik emocjonalny, poprzedzony wskaźnikiem kontaktów społecznych, zdolności poznawczych i na końcu wskaźnikiem samotności. W leczeniu holistycznym osób starszych, w którym czynnik psychologiczny jest jednym z czterech czynników, zarówno zmiany strukturalne jak i te w samym procesie są konieczne do osiągnięcia lepszych rezultatów, w tym przypadku, wyższego poziomu zadowolenia z życia w podeszłym wieku.

Słowa kluczowe: c cłlowiek w podeszłym wieku, emocje, kontakty społeczne, samotność, funkcje poznawcze, metoda propensity score matching

\section{CONNECTION BETWEEN PSYCHOLOGICAL HOLISTIC FACTOR AND LIFE SATISFACTION IN OLD AGE -}

\section{PROPENSITY SCORE METHODS}

Introduction. Holism has been poorly researched in the field of health and social gerontology. The old man is a whole, therefore he needs a holistic treatment. It means that we consider his bio-psycho-social and spiritual needs. The purpose of the research is to determine the relationship of a psychological holistic factor with life satisfaction in old age.

Material and methods. For the needs of the research work, a quantitative research method was used. A simple random sample was selected from the statistical set. The survey included 1064 elderly people in Slovenia (65 years and over) in ten statistical regions living in the domestic $(n=532)$ and institutional ( $n=532)$. Environment. Sample realization was $61.6 \%$ ( 656 correct questionnaires). According to demographic data, the survey involved 470 (71.6\%) women and $186(28.4 \%)$ men. The average age of the respondent was 78.2 years. The data was analyzed with the R MICE package. The analysis of causal effects and conditional associations advanced statistical methods, i.e. propensity score methods, and a questionnaire as a structured measurement instrument were used. 
Results. Obtained research results imply a scientific contribution in the field of quality management of people in old age and their life quality. On the basis of statistical calculations, the hypothesis that the psychological holistic factor $\left(R^{2}=0.21\right)$ is related to life satisfaction in old age is confirmed. We proved that indexes: social networks $\left(R^{2}=0.176\right)$, positive emotions $\left(R^{2}=0.366\right)$, loneliness $\left(R^{2}=0.151\right)$, cognitive abilities $\left(R^{2}=0.162\right)$ studied within a psychological holistic factor affect life satisfaction.

Discussion and conclusion. Research confirmed that within the psychological factor, the most intimately related to life satisfaction is the emotional index, followed by the index of social networks, cognitive abilities and the last index of loneliness. For the holistic treatment of old man, in which the psychological factor is the only one of the four holistic factors, both structural and process changes are required for achievement of better outcomes, in our case, higher levels of satisfaction with life in old age.

Key words: old man, life satisfaction, emotions, social networks, loneliness, cognitive functions, propensity score methods

\section{INTRODUCTION}

Aging is a natural process and a segment of the life course of every individual. Confronting an individual with age and adapting to age is very variable, so the rate of successful aging is also different. Successful aging is an expression which means greater flexibility [1] and is associated with the well-being and ability to adapt to the changes that age brings [2].

Holism in the Slovene area has been tackled only recently, therefore it is poorly researched in the field of health and social gerontology. According to McEvoy and Duffy, „whole" comes from the Greek word "holos", from which the term holistic (holistic) is derived. If we say that man is a whole, then he needs "whole"/holistic treatment including psycho-social and spiritual needs [3], as confirmed by the authors Hajdinjak and Meglič [4]. Helvie [5] developed the theory of healthy integral/holistic aging, focused on the individual as a whole, his mind and the environment. He emphasizes the interaction of an individual with the environment and describes how to stay healthy, have positive attitude, and enjoy positive environment in which he/she can develop and change. Components of healthy holistic aging are health, environment and relationships. The theory of reliability or general biological theory [6] is supposed to integrate the processes of aging in the organism holistically.

The psychological factor is one of the four holistic factors that we have developed on the basis of four indexes (social networks, emotions, loneliness and cognitive functions). Social networks are an important part of life quality of the individual and his/her satisfaction, and have positive effect on the subjective well-being of old man $[7,8]$. Price deals with social networks as means by which old people transmit their tensions/loads around them [9]. Hlebec states that quality of old-ageing has to be supported by sufficient social and health care [10]. The most important source of social support for older people are their family members [11]. Emotion is a mental process by which we express our subject-relation-value to person, action, often even to ourselves in a subjective way [12]. Experiencing life satisfaction and the frequency of negative emotions do not differ significantly between genders. Women and higher educated are more likely to experience positive emotions [13], while Musek [14] states that happiness and life satisfaction are more important when the basic needs are met. This is also confirmed by Diener [15] who says that happiness is important for people and affects life satisfaction. The personal, subjective sense of happiness is an indispensable condition of happiness in life, and hence also the quality of life. Zabukovec [16] also notes close connection between experiencing happiness and satisfaction with life.

Loneliness is a subjective feeling that we are alone [17]. Loneliness, a degree of reduced self-sufficiency and a feeling of being worried have a significant impact on life satisfaction [18]. Graham defines loneliness as a sense of lack of a person's important contacts with other people, accompanied by sadness and mental pain. [19] According to Maček, Skela Savič and Zurc, the sense of loneliness increases with age, due to the decline in the ability to move independently, the deterioration of family relationships and the aggravation of neighborly relations. Greater loneliness is present in elderly people who are single, separated and widowed, compared to old people who are related [20]. Elderly people with poor health often feel socially isolated, lonely and live in fear of the future [21], so isolation is often associated with chronic illness [22], and is a risk factor leading to serious health problems [23].

Cognitive functions at later age play an important role in the pursuit of everyday activities and independent living. In more complex decision-making situations, aging influences decision-making ability [24, 25]. Lavrač and Srakar find, that in all age groups, all cognitive functions are in decrease. Better educated performers have significantly better results in all cognitive functions, what is especially evident in memory functions [26]. Nay, Garratt and Fetherstonhaugh note that, despite physical limitations and the presence of memory disorders, centenarians have a positive view of life and are pleased with it. A further analysis showed that age is the only negative correlation with memory, what confirms that the risk of dementia increases with age [27]. The poor sleep causes problems with attention, memory and thinking [28]. Physical exercises affect the increase in the gray brain volume in the prefrontal cortex and the hippocampus, what enhances attention and memory [29].

\section{AIM}

The aim of the research is to find out the relationship between the four indexes (independent variable): social networks, emotions, isolation, cognitive functions and life satisfaction (dependent variable) within a psychological factor. 
The research hypothesis is the following: The psychological factor is related to the life satisfaction in old age.

\section{MATERIALS AND METHODS}

Quantitative research method was used.

We used the deductive method, which enables us, on the basis of general findings, to deduct the characteristics of an individual; causal non experimental method, with which we explain and look for sources of the present condition; the descriptive method, which enables the description of facts, processes and phenomena, and comparative method, with which we discover similarities and differences [30].

In order to collect the data, we drafted a survey questionnaire on the basis of literature. For measuring life satisfaction we used the Satisfaction with Life Scale - SWLS [31], which consists of five claims/statements. The level of agreement with the claims was evaluated by the respondents according to a seven-stage scale (1-Strongly disagree, 2-Disagree, 3-Slightly disagree, 4-Neither agree nor disagree, 5-Slightly agree, 6-Agree and 7-Strongly agree). The SWLS scale was translated into Slovenian language and validated. The consent for the conduction of the research was given by Dr. Ed Diener. In order to facilitate the understanding of the scoring according to the SWLS scale, we used the following ranges of scores: $30-35$ points - very high score (highly satisfied), 25-29 points - high score, 20-24 points - average score, 15-19 points - slightly below average in life satisfaction, 10-14 points dissatisfied, and 5-9 points - extremely dissatisfied (more at http://internal.psychology.illinois.edu/ ediener/Documents/Understanding\%20SWLS\%20Scores.pdf). Cronbach's coefficient alpha for SWLS scale was 0.848 .

The index „social networks” includes data on an informal social network, on relationships and communication within the social network of an elderly person. The index „emotions” includes data from the standardised questionnaire SPANE, Diener and Biswas-Diener [32]. The index „loneliness” refers to the identification of loneliness and includes data from the Oulu Wellness Profile - OLDWELLACTIVE [33] questionnaire. The fourth index, which we named „cognitive abilities”, includes data on memory, concentration and mood.

We used a simple random pattern. According to the size of the population of people aged 65 years and above, we chose, according to regions, proportionate stratified samples (sample sizes in stratums are proportional to the size of the stratum). For the accuracy of the sample we have chosen a confidence interval (+/-3\%). Such confidence interval means that if $70 \%$ of the respondents answer a certain question in the affirmative form, we can expect that the result of the entire studied population will lie with the reliability of $95 \%$ (alpha= 0.05 ) between $67 \%$ and $73 \%$.

In our research we included the sample of 1064 older adults, 532 living in home environment (urban or rural) and 532 in the social care institutions/homes for elderly (public or private institutions with concession) in each statistical region in Slovenia, reported by the Statistical Office of the Republic of Slovenia.
The number of correctly completed survey questionnaires was 656 , what means that the realization of the sample was $61.6 \%$. The realization of the sample was better in home environment $57.9 \%$ (380 out of 532). The share of older adults who have correctly and completely filled in the questionnaire in social care institutions represented $42.1 \%$ (276 out of 532) of all surveyed people in the population. Table 1 shows the demographic characteristics of the respondents.

Tab. 1. Demographic characteristics of respondents.

\begin{tabular}{|c|c|c|}
\hline \multicolumn{1}{|c|}{ Demographic factor } & $\mathbf{n = 6 5 6}$ & $\%$ \\
\hline Gender & 186 & 28.4 \\
\hline Male & 470 & 71.6 \\
\hline Female & 246 & 37.5 \\
\hline Marital status & 48 & 7.3 \\
\hline Married & 302 & 46.0 \\
\hline Single & 43 & 6.6 \\
\hline Widowed & 17 & 2.6 \\
\hline Divorced, separated &
\end{tabular}

\section{Education}

\begin{tabular}{|c|c|c|}
\hline Elementary education & 132 & 20.1 \\
\hline Vocational education & 146 & 22.3 \\
\hline Secondary (high school) education & 229 & 33.9 \\
\hline Higher education & 97 & 14.8 \\
\hline University graduates and post-graduate degrees & 52 & 7.9 \\
\hline \multicolumn{3}{|c|}{$A V \pm S D$} \\
\hline Age (in years) & $78.2 \pm 8.0$ & $65-98$ \\
\hline The amount of monthly income (in EUR) & $722 \pm 293$ & $0-1800$ \\
\hline
\end{tabular}

$\mathrm{n}=$ number; $\mathrm{AV}=$ average value; $\mathrm{SD}=$ standard deviation

The majority of respondents were widowed females; $33.9 \%$ of them have completed secondary (high school) education. The average age of the respondents was 78.2 $(\mathrm{SD}=8.0)$ years and their average monthly income was 722 (SD=293) EUR. Some of the respondents did not want to specify the amount of their monthly income.

The data were collected in ten statistical regions across Slovenia. The procedure of data collection took place in domestic environment (in the homes of old people, at the meetings in local communities, day activity centres, at social gatherings of retired people) and in 21 social care institutions/homes for elderly. As many as 43 interviewers were involved in the process of data collection. In order to complete the questionnaire, in home environment elderly people needed from 45 to 60 minutes for the task, whereas in social care institutions they needed up to 120 minutes to complete the questionnaire. Data collection took place from June $1^{\text {st }}, 2014$ until September 30 ${ }^{\text {th }}, 2015$.

In order to be able to show the desired influences or interconnections between psychological factor and life satisfaction we used the advanced statistical methods for the analysis of causal effects and conditional associations, that is the so called propensity score methods [34]. Propensity score methods are intended for association 
or causal effect statistical analysis of balanced study design, and enable the comparison of two statistically comparable groups. Our aim was to show as reliable estimates of associations as possible, which are contingent on the variables and used to balance the data/study plan.

Before carrying out the study, we obtained a permission of the Commission for Scientific Research of the Faculty of Organisational Studies in Novo Mesto, where the Commission assessed the ethical aspects of the research. The Commission for Scientific Research made the decision (Item no.: 130-014/ 2014 dated 21 ${ }^{\text {st }}$ March 2014) that the study and the measurement instrument take into account all ethical aspects of research and that they are appropriate for conducting the research. All respondents who were included in the study were acquainted with the purpose and the course of the study beforehand. Each respondent gave an informed consent prior to the inclusion in the study. They were told that they can withdraw during the course of the study.

Methodology of the analysis: Since this is a comparative study of the data that have not been collected on the basis of completely randomised design, but with a survey, we first balanced the study plan so that the group of those with a high level of the index is comparable to the group with a low level of the index. To carry out this process, we used a propensity score [35], which is a balancing score and methods of matching [36], [37]. The propensity score was estimated on the basis of the observed covariates, which were selected based on the logicality with regard to the studied data and the objective of the analysis (influence of factors on life satisfaction). The objective was that the models for assessing the propensity score in all comparability studies would be the same. This means that all the comparability studies would be made on the study plan which is balanced based on the same covariates. Selected observed covariates are the following: gender, education, location of residence and age. The propensity score was estimated by using logistic regression where we used the following model:

$\operatorname{logit}(\mathrm{IK})=b_{0}+b_{1}$ gender $+b_{2}$ education*location $+b_{3}$ age*gender

where IK represents each index within each individual studied factor. For the criterion of model specification we used the balance of observed covariates. The selected model enabled us to balance observed covariates between units that reach the high and low levels of each index. To carry this out we used the package R of MICE [38].

\section{RESULTS}

\section{Social network}

A Welch t-test comparison of a harmonized pattern between individuals with a high and low social network index estimates that there is a statistically significant difference between the groups (Table 2). As seen in Table 2, those with a high social network index $\left(\bar{X}_{\mathrm{v}}=24.673\right)$ are more satisfied with their lives than those with a low social network index $\bar{X}_{N}=20.888$. The average values of satis- faction with the lives of both groups fall into the same category according to SWLS, i.e. group with average satisfaction ranging from 20 to 24 points. The result shows that a group of elderly people with a higher level of social network is crossing the marginal value and approaching 25 , where the next level begins - a high level of satisfaction with life. A group with a lower social network has slightly exceeded the threshold of categories slightly below the average in satisfaction and average satisfaction with life. Individuals with a high social network index, according to the SWLS scale (Satisfaction with life), achieve almost high level of satisfaction on average $\left(\overline{\mathrm{X}}_{\mathrm{v}}=24.673\right)$.

Tab. 2. Welch t-test for the social network index.

\begin{tabular}{|c|c|c|c|c|c|}
\hline $\begin{array}{c}\text { Social } \\
\text { network }\end{array}$ & $\overline{\mathbf{X}}_{\mathbf{v}}$ & $\overline{\mathbf{X}}_{\mathbf{n}}$ & $\begin{array}{c}95 \% \text { confidence } \\
\text { interval for } \\
\text { the difference } \\
\text { between } \overline{\mathbf{X}}_{\mathbf{v}} \text { in }\end{array}$ & p-value & Effective n \\
\hline $\begin{array}{l}\text { Welch t-test } \\
\text { Comparison } \\
\text { of two samples }\end{array}$ & 24.673 & 20.888 & {$[2.678,4.893]$} & 0.000 & $\begin{array}{c}59.76 \% \\
n=392\end{array}$ \\
\hline
\end{tabular}

Table 2 shows that the effective sample used in the analysis of this index was $59.76 \%$ of the total sample. There is $95 \%$ possibility that the difference between the groups is within the obtained interval [2.678, 4.893].

Tab. 3. Assessment of conditional association between the social network and life satisfaction.

\begin{tabular}{|l|c|c|c|c|}
\hline & $\begin{array}{c}\text { Estimated } \\
\text { value }\end{array}$ & $\begin{array}{c}\text { Standard } \\
\text { deviation }\end{array}$ & p - value & Effective n \\
\hline Social network & 22.407 & 2.459 & 0.000 & $\begin{array}{c}59.76 \% \\
\mathrm{n}=392\end{array}$ \\
\hline
\end{tabular}

Assessment of the conditional association (Table 3) shows positive correlation between life satisfaction and the social network. When the social network of an elderly person improves and all other factors remain unchanged, the individual's life satisfaction increases.

\section{Emotions}

A Welch t-test comparison of a harmonized sample between individuals with a high and low emotion index estimates that there is a statistically significant difference between the groups (Table 4). As seen in Table 4, those with a high emotional index $\overline{\mathrm{X}}_{\mathrm{v}}=24.389$ are more satisfied with life than those with a low emotional index $\overline{\mathrm{X}}_{\mathrm{N}}=17.611$. Individuals with a high emotional index have passed the bounds of average life satisfaction (up to 24) and are approaching the threshold of high life satisfaction $\left(\bar{X}_{\mathrm{v}}=24.389\right)$. Individuals with low emotions index on average achieve a little below average in life satisfaction $\left(\bar{X}_{\mathrm{N}}=17.611\right)$.

Tab. 4. Welch t-test for the emotions index.

\begin{tabular}{|l|c|c|c|c|c|}
\hline Emotions & $\overline{\mathbf{X}}_{\mathbf{v}}$ & $\overline{\mathbf{X}}_{\mathbf{n}}$ & $\begin{array}{c}\mathbf{9 5 \%} \text { confidence } \\
\text { interval for } \\
\text { the difference } \\
\text { between } \overline{\mathbf{X}}_{\mathbf{v}} \text { in } \overline{\mathbf{X}}_{\mathbf{n}}\end{array}$ & p-value & Effective n \\
\hline $\begin{array}{l}\text { Welch t-test } \\
\text { Comparison } \\
\text { of two samples }\end{array}$ & 24.389 & 17.611 & {$[5.195,8.361]$} & 0.000 & $\begin{array}{c}27.44 \% \\
\mathrm{n}=180\end{array}$ \\
\hline
\end{tabular}


Table 4 shows that the effective sample used in the index analysis is 180 or $27.44 \%$ of the total sample. There is $95 \%$ possibility that the difference between the groups is in the obtained interval $[5.195,8.361]$.

Tab. 5. Assesment of the conditional association between emotions and life satisfaction.

\begin{tabular}{|l|c|c|c|c|}
\hline & $\begin{array}{c}\text { Assessed } \\
\text { value }\end{array}$ & $\begin{array}{c}\text { Standard } \\
\text { deviation }\end{array}$ & p-value & Effective $\mathbf{n}$ \\
\hline Emotions & 0.4523 & 0.045 & 0.000 & $\begin{array}{c}27.44 \% \\
\mathrm{n}=180\end{array}$ \\
\hline
\end{tabular}

The assessment of the conditional association shows a positive correlation between satisfaction with life and emotions (Table 5). Positive emotions are related to life satisfaction. Older people with more positive emotions are more satisfied with life in old age.

\section{Loneliness}

The Welch t-test comparison of a harmonized samples between individuals with a high and low loneliness index estimates that the difference between the groups is statistically significant (Table 6). Those with a high index of loneliness $\bar{X}_{v}=24.358$ are more satisfied with life than those with a low index of isolation $\bar{X}_{N}=20.791$. Despite the statistically significant difference, the average values of life satisfaction in both groups fall into the same category according to SWLS, i.e. group with average satisfaction ranging from 20 to 24 points. The result shows that a group of elderly people with a lower level of loneliness crosses the marginal value and approaches 25 , where the next level begins - a high level of satisfaction with life. A group with a higher value of loneliness has slightly exceeded the threshold of categories slightly below the average in satisfaction and average life satisfaction.

Tab. 6. Welch t-test for the loneliness index.

\begin{tabular}{|l|c|c|c|c|c|}
\hline Loneliness & $\overline{\mathbf{X}}_{\mathbf{v}}$ & $\overline{\mathbf{X}}_{\mathbf{n}}$ & $\begin{array}{c}95 \% \text { confidence } \\
\text { interval for } \\
\text { the difference } \\
\text { between } \overline{\mathbf{X}}_{\mathbf{v}} \text { in }\end{array}$ & p-value & Effective $\mathbf{n}$ \\
\hline $\begin{array}{l}\text { Welch t-test } \\
\text { Comparison } \\
\text { of two samples }\end{array}$ & 24.358 & 20.791 & {$[2.573,4.561]$} & 0.000 & $\begin{array}{c}77.44 \% \\
n=508\end{array}$ \\
\hline
\end{tabular}

In Table 6 it is evident that the effective sample used in the index analysis is 508 i.e. $77.44 \%$ of the total sample. There is $95 \%$ possibility that the difference between the groups is in the interval $[2.573,4.561]$.

Tab. 7. Assessment of conditional association between loneliness and life satisfaction.

\begin{tabular}{|l|c|c|c|c|}
\hline & $\begin{array}{c}\text { Assessed } \\
\text { value }\end{array}$ & $\begin{array}{c}\text { Standard } \\
\text { deviation }\end{array}$ & p -value & Effective $\mathbf{n}$ \\
\hline Loneliness & 10.416 & 1.098 & 0.000 & $\begin{array}{c}77.44 \% \\
\mathrm{n}=508\end{array}$ \\
\hline
\end{tabular}

Since the loneliness variable has been reversed (loneliness index value close to 0 means high loneliness and the value of the index close to 1 means low isolation), in order to have the coordination process resulting in a more effective sample, the interpretation of the positive estimate of the conditional association (10.416) is as follows: when an elderly man is less lonely, or loneliness is reduced, life satisfaction increases.

\section{Cognitive abilities}

The Welch t-test comparison of a harmonized sample between individuals with a high and low cognitive capacity index (memory, concentration and mood) estimates that the difference between the groups is statistically significant (Table 8). As seen in Table 8, those with a high index of cognitive abilities $\overline{\mathrm{X}}_{\mathrm{v}}=24.277$ are more satisfied with life than those with a low index of isolation $\bar{X}_{N}=20.120$ Despite the statistically significant difference, the average values of life satisfaction of both groups fall into the same category according to SWLS, i.e. group with average satisfaction ranging from 20 to 24 points. The result shows that a group of older people with a higher level of cognitive abilities, over the edge of the threshold value is approaching a value of 25 where the next level begins - a high level of satisfaction with life. A group with lower cognitive abilities has slightly exceeded the threshold of categories slightly below the average and average life satisfaction.

Tab. 8. Welch t-test for the cognitive abilities index.

\begin{tabular}{|l|c|c|c|c|c|}
\hline $\begin{array}{c}\text { Cognitive } \\
\text { abilities }\end{array}$ & $\overline{\mathbf{X}}_{\mathbf{v}}$ & $\overline{\mathbf{X}}_{\mathbf{n}}$ & $\begin{array}{c}95 \% \text { confidence } \\
\text { interval for } \\
\text { the difference } \\
\text { between } \overline{\mathbf{X}}_{\mathbf{v}} \text { in } \overline{\mathbf{X}}_{\mathbf{n}}\end{array}$ & p-value & Effective n \\
\hline $\begin{array}{l}\text { Welch t-test } \\
\text { Comparison } \\
\text { of two samples }\end{array}$ & 24.277 & 20.120 & {$[3.145,5.168]$} & 0.000 & $\begin{array}{c}77.44 \% \\
\mathrm{n}=508\end{array}$ \\
\hline
\end{tabular}

Table 8 shows that the effective sample used in the analysis of this index is 508 i.e. $77.44 \%$ of the total sample. It means that there is $95 \%$ possibility that the difference between the groups is in the interval $[3.145,5.168]$.

Tab. 9. Assesment of conditional association between cognitive abilities and life satisfaction.

\begin{tabular}{|l|c|c|c|c|}
\hline & $\begin{array}{c}\text { Assessed } \\
\text { value }\end{array}$ & $\begin{array}{c}\text { Standard } \\
\text { deviation }\end{array}$ & $\mathbf{p}$-value & Effective n \\
\hline Loneliness & 10.416 & 1.098 & 0.000 & $\begin{array}{c}77.44 \% \\
\mathrm{n}=508\end{array}$ \\
\hline
\end{tabular}

Among the cognitive abilities and life satisfaction, there is a positive association (Table 9). Satisfaction with life increases when the cognitive abilities of an elderly person improve and all other factors remain unchanged. 
Tab. 10. Multiple R square for single index.

\begin{tabular}{|c|c|c|c|}
\hline Index & Multiple square & R Effective n & $p$-value \\
\hline \multicolumn{4}{|c|}{ Psychological factor $\left(R^{2}=0.21\right)$} \\
\hline Social network & 0.176 & $\begin{array}{c}59.76 \% \\
n=392\end{array}$ & 0.000 \\
\hline Emotions & 0.366 & $\begin{array}{c}27.44 \% \\
n=180\end{array}$ & 0.000 \\
\hline Loneliness & 0.151 & $\begin{array}{c}77.44 \% \\
n=508\end{array}$ & 0.000 \\
\hline Cognitive abilities & 0.162 & $\begin{array}{c}77.44 \% \\
n=508\end{array}$ & 0.000 \\
\hline
\end{tabular}

Table 10 shows that all four indexes (independent variable) are linked to satisfaction with life in old age (dependent variable). It is evident that emotional index $\left(\mathrm{R}^{2}=0.366 ; \mathrm{p}=0.000\right)$ is the most strongly associated with the life satisfaction in old age, since it has a high value of multiple R-squares and was constructed on a methodologically completed construct (SPANE). The next index is social networks $\left(\mathrm{R}^{2}=0.176 ; \mathrm{p}=0.000\right)$, followed by the cognitive index $\left(\mathrm{R}^{2}=0.162 ; \mathrm{p}=0.000\right)$ and the last one is index isolation $\left(\mathrm{R}^{2}=0.151 ; \mathrm{p}=0.000\right)$. The estimates of multiple R-squares derive from a variance analysis that was made on harmonized data, what confirms the hypothesis.

\section{DISSCUSSION}

For the study of the psychological factor, four indexes were considered: social networks, emotions, loneliness and cognitive abilities. All four examined indexes turned out to be statistically significant (Table 10). The emotions index is more strongly linked with life satisfaction, the other three are weaker linked with it (Table 10).

The study found out that elderly people feel rather isolated in both domestic and institutional care, but there are no major differences in the frequency of loneliness with regard to the environment. Older people are slightly more depressed in home environment, aggression and hatred are rare or never present, they are rarely sad and do not feel hopeless. A good fifth of the elderly feel inferior to a greater extent than those who live in an institutional setting. When the old ones are alone, they most often watch television, read books, newspapers and magazines. Only few play some instrument and meditate. Loneliness is most often prevented by using a computer at home environment, while in an institutional setting they watch television. Education statistically does not affect memory problems, however, old people with only elementary education have more memory problems.

Elderly people who have a high index of social networking are more satisfied with life than those with a poorly developed social network. Older people living in home environment pointed out that they consider family social network (partner, children), as the most important one, while those who live in an institutional setting put the social network at care home in the first place, what is statistically significant. Friendly social network (friends, neighbors) means more to those who are at home.
Socializing with friends and neighbors can be interrupted or weakened by going to a social welfare institution. This can also be due to the fact that this network is decreasing due to death of the people. A voluntary social network has the least meaning to older people. Ramovš considers that the time and power that a person dedicates to his family, home, homelands and communities is an indispensable investment for quality aging and coexistence between generations [38]. Our findings also confirm that the elderly point out their need for help from the young and the middle aged generation.

Stegmüller and Bakračevič Vukman note that experiencing life satisfaction and frequency of negative emotions do not differ significantly between genders. Women are more likely to experience positive emotions [13], as our research has shown. We have found that there is no statistically significant difference in experiencing positive emotions between those who live alone and those who live in the community. All positive emotions according to SPANE were rated higher by women. According to Grün [39], men find it hard to cope with their emotions and inner life, what is also evident in the results of our research.

Musek [14] states that happiness and life satisfaction become more important when more basic needs are met. This is confirmed by Diener who says that happiness is important for people and affects life satisfaction. After ranking, happiness is in the first place for most respondents [15]. Living circumstances affect subjective mental well-being. Happiness does not depend only on innate temperament. According to age, older people are happier in the age group of 65-80 than in the age group of 81 and over.

More fortunate are people with higher education, but there is no statistically significant difference. Musek [14] says that mental well-being i.e. mental health is its core component and thus a key psychological aspect of the quality of life. Regarding negative emotions, the highest ranked negative feeling was sadness, more often present in women than men. Both negative emotions, fear and negativity are more present in older people living in home environment. Research confirmed that positive emotions are related to satisfaction with life. Older people who have more positive feelings are more satisfied with life.

The research of Plužarić showed that elderly people who live in their own house/flat are equally happy with life, as those living in social care institutions/homes for elderly [40], what differs from our finding that old people who live in a social welfare institution or a protected apartment are more satisfied with life than old people who live at home.

Most of the problems with memory are found among older people with elementary and vocational education and less in the group with university education. Between the groups, there is no statistically significant difference. Older people with lower education have more concentration problems. Lavrač and Srakar [26] found that better educated people have remarkably better results in all cognitive functions, especially memory ones. According to the values of cognitive functions, 
among the Mediterranean countries Slovenia is ranked below the average. It means that an old person should do cerebral exercises regularly to strengthen memory and to keep mental strength.

The hypothesis that the psychological factor is related to life satisfaction in old age is confirmed.

\section{CONCLUSIONS}

This research confirms that the individual as a whole is significantly influenced by a psychological factor that enables enjoyment of a satisfactory and quality life at a later age. Elderly people who have a well-developed social network are not lonely; they have no problems with memory, concentration, and mood (cognitive abilities) and express positive emotions. In order to take into account obtained results, both in home and in the social environment, certain organizational changes of the social gerontological services and individual providers of health have should be considered. For the holistic treatment of an elderly man, in which the psychological factor is only one of the holistic factors, both structural (organization of work, knowledge of practitioners, level of health literacy of old people, etc.) and process changes (individual treatment, old man oriented approach, establishing a partnership relationship, holistic treatment, etc.) are necessary. Changes will enable better outcomes: higher levels of life satisfaction in old age and will make home environment more responsive, while the institutional environment has to face the challenge of complex changes.

The originality of our research is reflected in the study of the psychological factor in the holistic model of life satisfaction in old age, which also includes physical, social and spiritual factors. The disadvantage of the performed study is that we did not carry out triangulation (examination from different angles), due to the scale and complexity of the quantitative research carried out in ten statistical regions. Given the research design, we did not choose a constructivist approach (qualitative paradigm), which would provide us with additional opportunities to seek in-depth answers to research questions.

\section{Limitation of research}

The survey had limitations in the selected methodology and sample size. The analysis was made on a balanced study plan, so the results can be generalized to the population of the elderly. A future study may analyze how individual indexes impact life satisfaction. The article with its originality is an important contribution to better understanding of life satisfaction and the meaning of the holistic treatment in old age.

\section{REFERENCES}

1. Martinson M, Berridge C. Successful Aging and Its Discontents: A Systematic Review of the Social Gerontology Literature. Gerontologist. 2015;55(1): 58-69. doi: 10.1093/ geront/gnu037.

2. Skela Savič B, Zurc J, Hvalič Touzery S. Staranje populacije, potrebe starostnikov in nekateri izzivi za zdravstveno nego. Obzornik zdravstvene nege. 2010;44(2): 89-100.

3. McEvoy L, Duffy A. Holistic practice - A concept analysis. Nurse Education in Practice. 2008; 8(6): 412-419. doi: 10.1016/j.nepr.2008.02.002.
4. Hajdinjak G, Meglič R. Sodobna zdravstvena nega. Ljubljana: Univerza v Ljubljani, Visoka šola za zdravstvo; 2012.

5. Helvie C0. Healthy Holistic Aging. United States of America: Syren Book Company, Minneapolis; 2007.

6. Gavrilov LA, Gavrilova NS. Reliability Theory of Aging and Longevity. [in:] Masoro EJ, Austad SN, eds. Handbook of the Biology of Aging. USA: Elsevier Academic Press; 2006, p. 3-42.

7. Mandič S. Kakovost življenja: med novimi blaginjskimi koncepti in družbenimi izzivi. Družboslovne razprave, XXI. 2005; (48): 111-131.

8. Pinquat $M$, Sörensen $S$. Influences of socioeconomic status, social network, and competence on subjective well-being in later life: a meta-analysis. Psychology and Aging. 2000; 15(2): 187-224. doi: http://dx.doi.org/10.1037/0882-7974.15.2.187.

9. Price B. Approaches to counter loneliness and social isolation. Nursing Older People. 2015; 27(7): 31-39. doi: http://dx.doi.org/10.7748/nop.27.7.31.e722.

10. Hlebec V. Socialna opora starostnikov v perspektivi spolov. Teorija in praksa. 2004; 41(5-6): 992-1007.

11. Filipović M, Kogovšek T, Hlebec V. Starostniki in njihova vpetost v sosedska omrežja. Družboslovne razprave, XXI. 2005; 49(50): 205-221.

12. Čustvo. Available at: https://sl.wikipedia.org/wiki/Čustvo [accessed: 20. 06. 2017].

13. Stegmüller N, Bakračevič Vukman K. Zadovoljstvo z življenjem v povezavi $s$ pozitivnim in negativnim čustovanjem $v$ srednji in pozni odraslosti. Raziskava na slovenskem vzorcu odraslih. Antropos. 2012; 1-2 (225-226): 31-54.

14. Musek J. Psihologija življenja. Ljubljana: Inštitut za psihologijo osebnosti; 2010.

15. Diener E. Subjective Well-Being: The Science of Happiness and a Proposal for a National Index. American Psychologist. 2000; 55(1): 34-43. doi: http://dx.doi. org/10.1037/0003-066X.55.1.34.

16. Zabukovec M. Kaj materialnega pogrešajo? [in:] Ramovš J, ed. Staranje v Sloveniji. Ljubljana: Inštitut Antona Trstenjaka za gerontologijo in medgeneracijsko sožitje; 2013, p. 179-188.

17. Kristančič A. Nova podoba staranja - siva revolucija. Ljubljana: AA Inserco; 2005.

18. Borg C, Halberg IR, Blomqvist K. Life satisfaction among older people (65+) with reduced self-care capacity: the relationship to social, health and financial aspects. Journal of Clinical Nursing. 2006; 15(5): 607-618. doi: 10.1111/j.13652702.2006.01375.x.

19. Graham J. The high Price of Loneliness; 2012. Available at: http://newoldage.blogs nytimes.com/2012/06/18/the-high-price-of-Ioneliness/?_r=0

20. Maček B, Skela Savič B, Zurc J. Dejavniki socialne integracije starostnika v domačem okolju. Obzornik zdravstvene nege. 2011; 45(3): 181-187.

21. Znika $M$, Telebuh $M$, Županić $M$, et al. Kvaliteta života svakodnevne životne potrebe starijih ljudi u urbanoj sredini. [in:] Filej $B$, ed. 4. Mednarodna znanstvena konferenca: Za človeka gre: družba in znanost v celostni skrbi za človeka, Maribor 11. - 12. marec. Maribor: Alma Mater Europaea - ECM; 2016, p. 299.

22. Alpass FM, Neville $S$. Loneliness, health and depression in older males. Aging \& Mental Health. 2003; 7(3): 212-216. doi: 10.1080/1360786031000101193.

23. Josić l, Pluzarić J, Ilakovac V, Barać I. Usamljenost osoba treće životne dobi s obzirom na stanovanje. [in:] Železnik D, Železnik U, Gmajner S, eds. 4. znanstvena konferenca z mednarodno udeležbo s področja zdravstveni ved: Pomen kompetentne obravnave uporabnikov zdravstveni in socialnih storitev v času krize, Laško 9. september 2014. Slovenj Gradec: Visoka šola za zdravstvene vede; 2014, p. 113-120.

24. Frey R, Mata R, Hertwig R. The role of cognitive abilities in decisions from experience: Age differences emerge as a function of choice set size. Cognition. 2015; 142: 60-80 doi: 10.1016/j.cognition.2015.05.004.

25. Zupančič M. Spoznavni razvoj in vsakdanja kompetentnost v pozni odraslosti. [in:] Marjanovič Umek L, Zupančič M, eds. Razvojna psihologija. Ljubljana: Znanstvenoraziskovalni inštitut Filozofske fakultete, 2004, p. 774-805.

26. Lavrač V, Srakar A. Kognitivne sposobnosti starejših. [in:] Majcen B, ed. Značilnosti starejšega prebivalstva v Sloveniji - prvi rezultati raziskave SHARE. Ljubljana: Inštitut za ekonomska raziskovanja; 2015, p. 37-49.

27. Nay R, Garratt $S$, Fetherstonhaugh D. Older People: issues and innovations in care (4 th Edition). Sydney: Churchill Livingstone: Elsevier Australia; 2014.

28. Pečjak V. Psihologija staranja. Bled: samozaložba; 2007.

29. Koščak Tivadar,B. Spomin v starosti in povezava s telesno dejavnostjo. [in:] Kregar Velikonja N, ed. Mednarodna znanstvena konferenca: Celostna obravnava pacienta: starostnik v zdravstvenem in socialnem varstvu, Novo mesto 12. november 2015. Novo mesto: Fakulteta za zdravstvene vede; 2015, p. 37

30. Rodica B. Raziskovalno delo v zdravstveni negi (učno gradivo). Novo mesto: Visoka šola za zdravstvo; 2012.

31. Diener E, Emmons RA, Lassen RJ, Griffin S. The Satisfaction With Life Scale. Journal of Personality Assessment. 1985; 49(1): 71-75.

32. Diener E, Biswas-Diener R. Scale for Positive and Negative Eperience (SPANE), 2009. Available at: https://internal.psychology.illinois.edu/ ediener/Documents/ Scale\%20of\%20Positive\%20and\%20Negative\%20Experience.pdf 
33. Koistinen POI, Elo $S$, Ahlroth M, et al. OLDWELLACTIVE - A self-rated wellness profile for the assessment of wellbeing and wellness activity in older people. European Geriatric Medicine. 2013; 4(2): 82-85. doi: http://dx.doi.org/10.1016/j. eurger.2012.09.007.

34. Rubin DB. Matched sampling for Causal Effects. New York: Cambridge University Press; 2006.

35. Rosenbaum PR, Rubin DB. The Central Role of the Propensity Score in Observational studies for Causal effects. Biometrika. 1983; 70(1): 41-55.

36. Chapin F. Experimental Designs in Sociological Research. New York: Harper; 1947.

37. Greenwood E. Experimental sociology, a study in method. New York: King's Crown Press, 1945.

38. Ramovš J. Za kakovostno staranje in lepše sožitje med generacijami. Ljubljana: Inštitut Antona Trstenjaka; 2009.

39. Grün A. Živimo zdaj! 0 sreči staranja. Ljubljana: Mladinska knjiga; 2012.

40. Plužarić J. Samopoštovanje in kvaliteta života starijih osoba. (Završni rad). Sveučilište Josipa Jurja Strossmayera u Osijeku, Medicinski fakultet, 0sijek; 2012.

Manuscript received: 10.07 .2017

Manuscript accepted: 15.09.2017

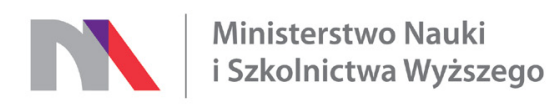

„Konsultacje z zagranicznymi naukowcami i wprowadzenie dwujęzycznych (j. polski/angielski) treści do czasopisma Pielęgniarstwo XXI wieku" finansowane w ramach umowy 547/P-DUN/2016 ze środków Ministra Nauki i Szkolnictwa Wyższego przeznaczonych na działalność upowszechniającą naukę. 